\title{
EFEKTIFITAS SOSIALISASI KONSELING SEBAYA TERHADAP PENGETAHUAN PENDEWASAAN USIA PERKAWINAN (PUP) DI KELURAHAN RANGKASBITUNG BARAT KECAMATAN RANGKASBITUNG KABUPATEN LEBAK
}

\author{
Nintinjri Husnida ${ }^{1}$, Melly Halimatussaadiah ${ }^{1}$ \\ ${ }^{1}$ Jurusan Kebidanan Poltekkes Kemenkes Banten \\ Korespondensi: nintin_gh@yahoo.co.id
}

\begin{abstract}
The problem of early marriage can be anticipated by providing knowledge about Marriage Age Maturity (PUP) in adolescents with peer methods. This study aims to determine the effectiveness of peer counseling socialization on knowledge of marriage age maturity (PUP) in the West Rangkasbitung Village, Rangkasbitung District, Lebak Regency, 2017. The design in this study was quasi-experimental. Research variables: peer counseling and knowledge of Marriage Age Maturity. Data was collected by questionnaire. Samples found were 18 teenagers.

The results showed that there were significant differences in the average value of knowledge before and after intervention $(p=0,000)$. Conclusion of this study, that learning using peer counseling has the role of increasing knowledge of Marriage Age Maturity in adolescents.
\end{abstract}

Keywords: Peer Counseling, Marriage Age Maturity

\begin{abstract}
ABSTRAK
Masalah pernikahan usia dini dapat diantisipasi dengan memberikan pengetahuan mengenai Pendewasaan Usia Perkawinan (PUP) pada remaja dengan metode teman sebaya. Penelitian ini bertujuan untuk mengetahui Efektifitas Sosialisasi Konseling Sebaya Terhadap Pengetahuan Pendewasaan Usia Perkawinan (PUP) Di Kelurahan Rangkasbitung Barat Kecamatan Rangkasbitung Kabupaten Lebak Tahun 2017. Rancangan yang digunakan dalam penelitian ini adalah dengan kuasi eksperimen. Variabel penelitian : konseling sebaya dan pengetahuan PUP. Data dikumpulkan dengan kuesioner. Sampel yang ditemukan sebanyak 18 remaja.

Hasil penelitian menunjukkan ada perbedaan yang signifikan rata-rata nilai pengetahuan PUP sampel intervesi sebelum dan sesudah diberi perlakuan $(p=0,000)$. Simpulan penelitian ini, bahwa pembelajaran menggunakan konseling teman sebaya berperan meningkatkan pengetahuan pendewasaan usia perkawinan pada remaja.
\end{abstract}

Kata Kunci: Konseling Teman Sebaya, Pendewasaan Usia Perkawinan 


\section{PENDAHULUAN}

Pernikahan dini adalah pernikahan yang dilakukan di bawah usia yang tidak seharusnya serta belum siap dan matang untuk melaksanakan pernikahan dan menjalani kehidupan rumah tangga (Nukman, 2009). Menurut UU No 1 Perkawinan tahun 1974 bahwa usia hukum minimum yang ditetapkan untuk menikah bagi perempuan 16 tahun dan 18 tahun untuk laki-laki.

Dalam aspek pernikahan, Survei Demografi dan Kesehatan Indonesia (SDKI) 2007 melaporkan bahwa dari 6.341 perempuan usia 15-19 tahun, $12,8 \%$ dari mereka sudah menikah dan dari 6.681 perempuan usia 20-24 tahun, $59,2 \%$ diantaranya sudah menikah. Usia 15-24 tahun oleh UNFPA dianggap sebagai pemuda dan 15-19 tahun sebagai remaja akhir, sehingga jelas bahwa remaja berdasarkan SDKI 2007 menikah pada usia yang lebih muda. Menurut laporan SDKI 2007 juga, sebanyak 4,3\% perempuan pada umur 15 tahun telah menikah pertama kali.

Pernikahan dini menurut BKKBN adalah pernikahan di bawah umur yang disebabkan oleh faktor social, pendidikan, ekonomi, budaya, faktor orang tua, faktor diri sendiri dan tempat tinggal. Menurut UU Perlindungan Anak No. 23 Tahun 2012, yaitu mereka yang belum berusia delapan belas tahun. Maka, siapapun yang menikah di bawah batas usia tersebut dapat dikatakan termasuk dalam pernikahan dini dan pernikahan dini ini banyak terjadi pada masa remaja.

Masa remaja adalah masa pada saat anak matang secara seksual dan berakhir sampai ia matang secara hukum, rata-rata batasan usia remaja berkisar antara usia 12 hingga 24 tahun, dengan pembagian fase remaja awal berkisar antara usia 12 -15 tahun, fase remaja madya berkisar antara usia 15 - 18 tahun dan fase remaja akhir berkisar antara usia $18-21$ tahun. Batasan maksimum usia 24 tahun, untuk individu yang belum dapat memenuhi persyaratan kedewasaan secara sosial maupun psikologis dan belum menikah. (Sarwono, 2006)

Oleh karena itu perkawinan diizinkan bila laki-laki berumur minimal 21 tahun dan perempuan minimal berumur 19 tahun, sehingga perkawinan usia muda adalah 
perkawinan yang dilakukan bila pria kurang dari 21 tahun dan perempuan kurang dari 19 tahun.

Menurut data penelitian Pusat Kajian Gender dan Seksualitas Universitas Indonesia tahun 2015, angka pernikahan dini di Indonesia peringkat kedua di kawasan Asia Tenggara. Ada sekitar 2 juta dari 7,3 perempuan Indonesia di bawah umur 15 tahun sudah menikah dan putus sekolah. Jumlah ini diperkirakan akan meningkat menjadi 3 juta orang di tahun 2030 .

Di Provinsi Banten terdapat sebesar 1,71 persen anak perempuan berumur 10-17 tahun berstatus kawin dan pernah kawin dengan persentase terbesar terdapat di Kabupaten Lebak (4,52 persen) dan persentase terkecil terdapat di Kota Tangerang (0,23 persen).

Persentase anak perempuan berumur 10-17 tahun yang berstatus kawin dan pernah kawin di daerah pedesaan sebesar 2,69 persen, dengan rincian sebesar 2,34 persen berstatus kawin dan 0,35 persen berstatus cerai hidup. Sementara untuk daerah perkotaan sebesar 1,20 persen, dengan rincian sebesar 1,20 persen berstatus kawin dan 0,00 persen berstatus cerai hidup.

Kecenderungan melakukan perkawinan pada usia muda di daerah pedesaan dipengaruhi oleh berbagai hal seperti faktor ekonomi, pendidikan, budaya dan lain-lain. Sebagian orang tua di perdesaan menikahkan anaknya dengan harapan setelah anak menikah dapat meringankan beban ekonomi keluarga. Selain itu, pada umumnya anak perempuan yang memasuki usia remaja dan belum menikah akan dianggap sebagai perawan tua. Hal inilah yang menyebabkan perkawinan pada usia muda di daerah perdesaan lebih tinggi dibanding daerah perkotaan. (Profil Anak Provinsi Banten Tahun 2014)

Perempuan yang menikah di bawah umur 20 tahun beresiko terkena kanker leher rahim, pada usia remaja sel-sel leher rahim belum tumbuh dengan matang. Kalau terpapar oleh Human Papiloma Virus (HPV) maka pertumbuhan sel akan menyimpang menjadi kanker. Kanker leher rahim menduduki peringkat pertama kanker yang menyerang perempuan Indonesia, angka kejadiannya saat ini $23 \%$ diantara kanker lainnya. Remaja akan 
mengalami masa reproduksi lebih panjang, sehingga memungkinkan banyak peluang besar untuk melahirkan dan mempunyai anak. (Burhani,2009)

Reproduksi sehat untuk hamil dan melahirkan adalah usia 20-30 tahun, jika terjadi kehamilan di bawah atau di atas usia tersebut maka akan dikatakan beresiko akan menyebabkan terjadinya kematian 2-4x lebih tinggi dari reproduksi sehat (Manuaba, IBG. 2010) .

Akibat pernikahan dini, para remaja saat hamil dan melahirkan akan sangat mudah menderita anemia. Dan ketidaksiapan fisik juga terjadi pada remaja yang melakuakan pernikahan dini akan tetapi juga terjadi pada anak yang dilahirkan. Dampak buruk tersebut berupa bayi lahir dengan berat rendah, hal ini akan menjadikan bayi tersebut tumbuh menjadi remaja yang tidak sehat, tentunya ini juga akan berpengaruh pada kecerdasan anak dari segi mental (Manuaba,2001).

Pernikahan dini juga menghentikan kesempatan seorang remaja meraih pendidikan yang lebih tinggi, berinteraksi dengan lingkungan teman sebaya, sehingga dia tidak memperoleh kesempatan pengetahuan dan wawasan yang lebih luas, hal ini juga berimplikasi terhadap kurangnya informasi dan sempitnya dia mendapatkan kesempatan kerja, otomatis lebih mengekalkan kemiskinan.

Dari sisi sosial pernikahan dini merupakan salah satu faktor penyebab tindakan kekerasan terhadap istri, ini timbul karena tingkat berfikir yang belum matang bagi pasangan muda tersebut. Data statistik lengkap mengenai Kekerasan Dalam Rumah Tangga (KDRT atau domistik violence) Mitra Perempuan Women's Crisis Center di Yogyakarta menyebutkan selama periode 1994 sampai 2004, menerima pengaduan 994 kasus kekerasan yang terdata, selanjutnya Menteri Negara Pemberdayaan Perempuan menyabutkan 11,4\% dari 217 juta penduduk Indonesia atau setara dengan 24 juta perempuan mengaku pernah mengalami kekerasan dalam rumah tangga (Dlori,2005).

Permasalahan remaja termasuk didalamnya masalah pernikahan dini melalui program kesehatan reproduksi remaja (WHO, 2006). Pemerintah telah 
menunjuk Badan Kependudukan dan Keluarga Berencana (BKKBN) dalam mengatasi permasalahan remaja dengan mengembangkan program Kesehatan Reproduksi Remaja (KRR). Program KRR termasuk salah satu program pokok yang tercantum dalam Rencana Pembangunan Jangka Menengah (RPJM 2004- 2009).

Diharapkan melalui program ini setiap Kecamatan memiliki Pusat Informasi dan Konseling Kesehatan Reproduksi Remaja (PIK-KRR) yang dapat mengatasi dan menanggulangi permasalahan remaja termasuk pernikahan dini. Perempuan yang menikah pada usia dini mempunyai waktu yang lebih panjang berisiko untuk hamil dan angka kelahiran juga lebih tinggi (Wilopo, 2005).

Sebagaimana tertera dalam Undang-Undang No. 12 tahun 1992 tentang Perkembangan Penduduk dan Pembangunan Keluarga Sejahtera, perlunya pengendalian kuantitas, peningkatan kualitas dan pengarahan mobilitas penduduk agar mampu menjadi sumber daya yang tangguh bagi pembangunan dan ketahanan nasional. Untuk mengatasi angka kelahiran tinggi dan pengendalian jumlah penduduk, BKKBN tahun 2008 meluncurkan program Generasi Berencana (GenRe) yaitu melalui kegiatan Pendewasaan Usia Perkawinan (PUP). (Muadz dkk, 2008) Pendewasaan Usia Perkawinan (PUP) bertujuan untuk memberikan pengertian dan kesadaran kepada remaja agar di dalam merencanakan keluarga, mereka dapat mempertimbangkan berbagai aspek berkaitan dengan kehidupan berkeluarga, ditinjau dari aspek kesehatan, ekonomi, psikologi dan agama.

Program Pendewasaan Usia Perkawinan (PUP) dapat disosialisasikan dengan konsep konseling teman sebaya. Konseling teman sebaya adalah konseling yang dilakukan oleh seseorang dengan konselor yang umurnya sebaya sebagai seorang teman dengan tujuan agar seseorang lebih terbuka menceritakan permasalahanya kepada sesama teman, membantu teman yang kurang terbuka kepada guru/orang tua dan dapat membantu teman yang sedang bermasalah.

Perkembangan sosial pada masa remaja lebih melibatkan teman sebaya 
dibanding orang tua. Dibanding pada masa kanak-kanak, remaja lebih banyak melakukan kegiatan di luar rumah seperti kegiatan sekolah, ekstra kurikuler dan bermain dengan teman. Maka seorang konselor yang sebaya (teman) peranya lebih besar. Teman sebaya diakui dapat mempengaruhi pertimbangan dan keputusan seorang remaja tentang perilakunya. Teman sebaya merupakan sumber referensi utama bagi remaja dalam hal persepsi dan sikap yang berkaitan dengan gaya hidup.

Konseling Sebaya PKBR adalah Pendidik Sebaya yang punya komitmen dan motivasi yang tinggi untuk memberikan konseling PKBR bagi kelompok remaja sebayanya yang telah mengikuti pelatihan konseling PKBR dengan mempergunakan modul dan kurikulum standar yang telah disusun oleh BKKBN atau yang setara.

Berdasarkan uraian dan penelitian terdahulu yang dikemukan di atas maka peneliti merasa perlu untuk melakukan penelitian tentang Efektifitas Sosialisasi Konseling Sebaya Terhadap Pengetahuan Pendewasaan

Usia

Perkawinan (PUP) Di Kelurahan Rangkasbitung Barat Kecamatan
Rangkasbitung Kabupaten Lebak Tahun 2017.

\section{METODE}

Desain penelitian yang digunakan dalam penelitian ini adalah kuasi eksperimen (eksperimen semu) Yaitu penelitian yang memberikan intervensi pada responden, akan tetapi peneliti tidak bisa mengontrol variabel pengganggu terhadap terhadap efek yang sedang diamati.

Populasi penelitian adalah remaja yang memenuhi kriteria sampel, bersedia menjadi responden dan dinyatakan dalam surat persetujuan. Kriteria inklusi pemilihan sampel penelitian adalah Wanita atau pria dengan rentang usia $12-21$ tahun, belum menikah dan remaja yang bersedia dijadikan responden ,Kriteria ekslusinya adalah wanita atau pria dengan usia $<12$ dan $>21$ tahun, belum menikah dan remaja yang tidak bersedia dijadikan responden

Jumlah sampel ditentukan sebanyak 18 responden. Jumlah ini diambil berdasarkan teori Sugiyono (2007) bahwa jumlah sampel minimal untuk penelitian dengan perlakuan adalah $10-20$. 
HASIL

\section{Analisis Univariat}

Tabel 1

Distribusi Frekuensi Hasil Pre Test

Tentang PUP

\begin{tabular}{|c|c|c|c|}
\hline \multicolumn{2}{|c|}{ Tentang PUP } & 10 & 73 \\
\hline No & Pengetahuan & 11 & 60 \\
\hline Responden & & 12 & 73 \\
\hline 1 & 66 & 13 & 53 \\
\hline 2 & 46 & 14 & 86 \\
\hline 3 & 53 & 15 & 100 \\
\hline 4 & 60 & 16 & 40 \\
\hline 5 & 60 & 17 & 73 \\
\hline 6 & 40 & 18 & 66 \\
\hline 7 & 66 & - Jumlah & 1161 \\
\hline 8 & 93 & - Rerata & 65 \\
\hline
\end{tabular}

\begin{tabular}{ccr}
\hline 10 & 66 & \\
\hline 11 & 40 & \\
\hline 12 & 60 & di \\
\hline 13 & 40 & re \\
\hline 14 & 80 & $\mathbf{2}$ \\
\hline 15 & 100 & \\
\hline 16 & 33 & \\
\hline 17 & 60 & $\mathbf{1 0 8 2}$ \\
\hline Jumlah & $\mathbf{6 0}$ &
\end{tabular}

Berdasarkan tabel 2 dapat diketahui bahwa pengetahuan responden pada saat post test lebih dari rerata sebanyak $77,7 \%$.

Berdasarkan tabel 1 dapat diketahui bahwa pengetahuan responden pada saat pre test kurang dari rerata sebanyak $38 \%$.

Tabel 2

Distribusi Frekuensi Hasil Post Test Tentang PUP

\begin{tabular}{cc}
\hline $\begin{array}{c}\text { No } \\
\text { Responden }\end{array}$ & Pengetahuan \\
\hline 1 & 73 \\
\hline 2 & 46 \\
\hline 3 & 66 \\
\hline 4 & 66
\end{tabular}

\section{Analisis Bivariat}

Data hasil uji beda pengetahuan tentang PUP sebelum dan sesudah perlakuan Berikutnya disajikan tabel hasil pengukuran uji beda antara variabel sebelum dan sesudah perlakuan menggunakan uji statistik Mann Witney.

Tabel. 3

Uji Beda Pengetahuan Pre Test \& Post Test Oleh Teman Sebaya

\begin{tabular}{lccccc}
\hline & \multicolumn{2}{c}{ Pre test } & \multicolumn{2}{c}{ Post test } & \multirow{2}{*}{$\mathrm{P}$} \\
\cline { 2 - 4 } Variabel & $\mathrm{n}$ & $\mathrm{X}$ & $\mathrm{n}$ & $\mathrm{x}$ & \\
\hline Pengetahua & 108 & 6 & 116 & 6 & 0.03 \\
$\mathrm{n}$ & 2 & 0 & 1 & 5 & 5 \\
\hline
\end{tabular}


Dari tabel diketahui rerata pengetahuan pre test lebih rendah dari rerata pengetahuan post test. Dari hasil uji statistik Mann Whitney didapatkan nilai $\mathrm{P}(0,035)$ yang berarti ada perbedaan yang bermakna mengenai pengetahuan tentang PUP pada remaja dari hasil pre test dan hasil post test setelah mendapat konseling dari teman sebaya.

\section{PEMBAHASAN}

\section{Hasil Pre Test Tentang PUP}

Berdasarkan Tabel 1 didapatkan hasil bahwa rerata pengetahuan tentang PUP pada remaja sebesar 60. Dari hasil tersebut terdapat 7 orang remaja (38\%) yang memiliki pengetahuan tentang PUP di bawah rerata. Hal ini menunjukkan bahwa hampir setengah dari total responden msh memiliki pengetahuang dibawah rerata tentang PUP .

Hasil ini sejalan dengan
penelitian yang pernah dilakukan
lestari AP dkk tentang pengetahuan
remaja tentang PUP kategori cukup
dengan presentase $49,3 \%$. Hal ini
dikarenakan responden mempunyai

pengetahuan yang berbeda-beda tentang pendewasaan usia perkawinan.

Pengetahuan setiap individu dapat berbeda antara satu dengan yang lain karena banyak factor yang dapat mempengaruhi tingkat pengetahuan seseorang antara lain usia , pengalaman, lingkungan dan paparan media informasi.

Hasil penelitian lain yang mendukung menurut Nuhgraheni (2011) mengungkapkan bahwa pengetahuan remaja tentang pendewasaan usia perkawinan cukup.

Pengetahuan merupakan faktor dominan yang penting dalam membentuk tindakan seseorang. Pada penelitian ini masih terdapat nya pengetahuan remaja tentang PUP dibawah rerata di mungkinkan karena remaja tersebut memiliki latar belakang yang berbeda seperti tingkat pendidikan, umur, media informasi dan pengaruh lingkungan. Selain itu dimungkinkan karena belum terpaparnya informasi mengenai PUP sehingga remaja belum memiliki pengetahuan yang memadai. Oleh sebab itu upaya untuk meningkatkan pengetahuan remaja tentang PUP bisa 
didapatkan salah satunya melalui tambahan pengetahuan berupa informasi dan konseling yang bisa di berikan oleh teman sebaya.

\section{Hasil Posttest Tentang PUP}

Berdasarkan tabel 2 didapatkan hasil bahwa rerata pengetahuan post test remaja tentang PUP sebesar 65 . Adapun jumlah responden yang memiliki pengetahuan diatas rata-rata tentang PUP sebanyak 15 orang (83 $\%$ ) dan yang memiliki pengetahuan di bawah rata-rata sebanyak 3 orang (16 $\%)$. Angka ini menunjukkan untuk hasil pengetahuan post test remaja yang sudah diberikan konseling dengan teman sebaya tentang PUP mengalami peningkatan dibandingkan dengan hasil pre test.

Hasil ini sesuai dengan penelitian yang pernah dilakukan oleh putriani $\mathrm{N}$ yaitu salah satu factor yang mempengaruhu pengetahuan remaja tentang kesehatan reproduksi adalah teman. Dalam penelitiannya juga mengungkapkan sebagian yang menganggap teman orang yang penting $(32,3 \%)$ karena pada saat menginjak usia remaja biasanya cenderung ingin membuktikan diri dan tidak bergantung lagi pada orang tua dan biasanya pada usia remaja lebih merasa nyaman jika berada bersama teman-temannya, maka tidak heran bila remaja mempunyai kecenderungan untuk mengadopsi informasi yang di terima oleh temantemannya, tanpa memiliki dasar informasi yang signifikan dari sumber yang lebih dapat di percaya.

Pengetahuan merupakan hasil "tahu" dan ini terjadi setelah orang melakukan penginderaan terhadap suatu objek tertentu. Penginderaan terjadi melalui panca indera manusia. Sebagian besar pengetahuan manusia diperoleh melalui dan telinga. (Notoadmojo, 2005). Dengan kata lain pengetahuan bisa di dapat dengan menggunakan pancaindera dalam hal ini adanya interaksi atau konseling.

Dengan adanya konseling dengan maka seseorang akan mendapatkan informasi, dan dengan informasi tersebut maka akan menambah pengetahuan seseorang.

Penelitian lain yang memperkuat yaitu dalam proses pembelajaran dengan menggunakan tutor / teman sebaya terjadi proses membangun pengetahuan sehingga seorang tutor akan mendapatkan 
manfaat ketika memberikan rerata pengetahuan pre test. Hal ini penjelasan kepada tutee (remaja), tutor didapatkan dari hasil uji statistik mengintegrasikan kosep dan prinsip Mann Whitney didapatkan nilai $\mathrm{P}$ serta menghasilkan ide baru. sebesar 0,035 yang berarti secara Pertanyaan yang spesifik dan statistik yang berarti ada perbedaan mendalam dari remaja dapat yang bermakna mengenai merefleksikan pengembangan pengetahuan tentang PUP pada remaja pengetahuan dan tutor (teman sebaya) dari hasil pre test dan hasil post test membantu proses penguatan pemahamannya. (Depaz, 2008)

Meningkatnya pengetahuan remaja dari hasil post test setelah diberikan informasi oleh teman sebaya dimungkinkan karena remaja yang idealnya berusia relative muda sehingga lebih mudah menyerap informasi, dan mereka memiliki rasa ingin tahu yang tinggi ketika menghadapi teman sebaya. Selain itu remaja lebih mudah memahami apa yang sudah diberikan oleh teman sebaya karena mereka lebih merasa nyaman karena teman sebaya dianggap mereka memiliki perasaan dan dihadapkan pada situasi yang sama (masa remaja).

3. Hasil Uji Beda Pengetahuan Pre Test \& Post Test Oleh Teman Sebaya

Berdasarkan tabel 3, rerata setelah mendapat konseling dari teman sebaya.

Konseling sebaya adalah konseling yang dilakukan oleh anakanak atau remaja dengan tingkat kematangan atau usia yang kurang lebih sama. Salah satu fungsi terpenting dari kelompok konseling sebaya adalah untuk memberikan sumber informasi dan komparasi tentang dunia di luar keluarga. Melalui kelompok teman sebaya individu menerima umpan balik dari teman-teman mereka tentang kemampuan mereka.

Menurut penelitian Arjanggi, R menemukan bahwa metode dengan teman sebaya secara signifikan dapat meningkatkan pengetahuan tentang pengetahuan PUP. Selain itu juga penelitian tersebut mengungkapkan ada pengaruh metode teman sebaya pengetahuan post test lebih tinggi dari 
terhadap prestasi belajar dan meningkatkan prestasi belajar.

Penelitian yang dilakukan

Buhrmester (Santrock, 2009 : 394) menunjukkan bahwa pada masa remaja kedekatan hubungan dengan teman sebaya meningkat secara drastis, dan pada saat yang bersamaan kedekatan

hubunganremaja dengan orang tua menurun secara drastis.

Hasil penelitian Buhrmester dikuatkan oleh temuan Nickerson \& Nagle (2005 : 240) bahwa pada masa remaja komunikasi dan kepercayaan terhadap orang tua berkurang, dan beralih kepada teman sebaya untuk memenuhi kebutuhan akan kelekatan (attachment).

Penelitian Crosnoe dkk. (2008); Rubin, Fredstrom, dan Bowker (2008) dalam Santrock, (2009:394) menemukan bahwa karakteristik teman sebaya memiliki pengaruh yang penting terhadap perkembangan remaja. Hal ini antara lain terlihat pada rata-rata prestasi belajar yang tinggi secara konsisten telah menjadi prediktor bagi prestasi sekolah yang positif.
Adanya perbedaan yang signifikan dalam penelitian ini dikarenakan umunya usia remaja mengalami peningkatan kelekatan dengan teman sebaya. Karena biasanya remaja lebih nyaman bersama dengan temannya, merasa lebih diperhatikan dan rasa nyaman ketika menghadapi sebuah masalah.

Adapun upaya lain yang dapat dilakukan selain untuk meningkatkan pengetahuan remaja dari teman sebaya ini adalah peningkatan perubahan perilaku kearah sikap yang lebih baik, mampu memperbaiki prestasi dan meningkatkan harga diri remaja itu senidiri.

Adapun upaya yang bisa di tingkatkan selain pengetahuan untuk para remaja adalah dengan tambahan tentang pendewasaan usia perkawinan sehingga selain memahami mereka benar-benar bersedia untuk menghindari pernikahan usia dini.

\section{SIMPULAN}

1. Pengetahuan remaja sebelum diberikan konseling oleh sebaya dari hasil pre test tentang PUP didapatkan rerata 60 . Terdapat 38 
$\%$ remaja memiliki pengetahuan di bawah rerata.

2. Pengetahuan remaja setelah diberikan konseling oleh sebaya dari hasil post test tentang PUP didapatkan peningkatan rerata. Terdapat $83 \%$ remaja memiliki pengetahuan di atas rerata.

3. Terdapat perbedaan yang bermakna dari pengetahuan remaja sebelum dan sesudah diberikan konseling dari sebaya.

\section{DAFTAR PUSTAKA}

Agus akhmadi. Konseling sebaya dalam bimbingan konseling komprehensif, materi diklat teknis fungsional peningkatan kompetensi guru pertama bk) widyaiswara balai diklat keagamaan surabaya, h. 5

BKKBN, Buku Panduan Pendidikan Kesehatan Reproduksi bagi Calon Pengantin.Jakarta, 2006

BKKBN, Panduan Pengelolaan Pusat Informasi dan KonselingKesehatan Reproduksi Remaja.Jakarta, 2008

Bernardus Widodo. Konseling Sebaya (Peer Counseling). Makalah untuk Program Studi Bimbingan dan Konseling FKIP Universitas Katolik Widya Mandala Madiun.
Mary Rebecca 'Rivkha' Rogacion, Peer Counceling, A way of Life, (Manila: The Peer Counseling Foundation, 1982), h. 16.

Manuaba, Ida Bagus Gde 2010. Ilmu Kebidanan, Penyakit Kandungan dan Keluarga Berencana. Jakarta. Salemba

Muslikah Bimbingan Teman Sebaya Untuk Mengembangkan Sikap Negatif Terhadap Perilaku Seks Tidak Sehat. Jurnal Bimbingan Konseling 2 (1) (2013) Prodi Bimbingan dan Konseling, Program Pascasarjana, Universitas Negeri Semarang, Indonesia, h. 14. 34

Nukman, 2009 Yang Dimaksud Pernikahan Dini. Diunduh di Http:// www.ilhamnuddin . co.id Diakses pada tanggal 08 Februari 2017 Pukul 11.00 WIB

Prawiroharjo, Sarwono, 2006, Ilmu Kebidanan, Edisi Ketiga , Jakarta: YBP-SP.

Santock, J.W. Life Span DefelopmentPerkembangan Masa Hidup. (Alih Bahasa Achmad Chusairi dan Juda Damanik). (Jakarta. Erlangga) 2002, h. 287

Suwarjo, "Konseling Teman Sebaya (Peer Counseling) untuk Mengembangkan Resiliensi Remaja," Makalah Disampaikan dalam Seminar Pengembangan Ilmu Pendidikan FIP UNY, 29 Februari 2008. 